\title{
A NATUREZA JURÍDICA EXTRAORDINÁRIA DO TOMBAMENTO DOS ANTIGOS QUILOMBOS
}

\author{
THE EXTRAORDINARY LEGAL NATURE OF THE HERITAGE LISTING OF THE \\ OLD QUILOMBOS
}

\section{LA NATURALEZA JURÍDICA EXTRAORDINARIA DEL TOMBAMENTO DE LOS ANTIGUOS QUILOMBOS}

\author{
Francisco Humberto CunHa FiLHo \\ http://orcid.org/0000-0003-2770-6532 / http://lattes.cnpq.br/8382182774417592 / humbertocunha@unifor.br \\ Universidade de Fortaleza - UNIFOR. \\ Fortaleza, CE, Brasil.
}

PAUlo SÉrgio Freire Nogueira

http://orcid.org/0000-0001-9138-4633 / http://lattes.cnpq.br/9707939601101900 / paulosergiofreire@yahoo.com.br

Universidade de Fortaleza - UNIFOR.

Fortaleza, CE, Brasil.

\begin{abstract}
RESUMO
0 artigo 216, $\S 5^{\circ}$ da Constituição do Brasil determina o tombamento de documentos e sítios que contenham vestígios dos antigos Quilombos. No entanto, o cumprimento deste dispositivo está comprometido por dois motivos principais: o primeiro envolve a discussão teórica materializada na dúvida sobre o entendimento do que seja Quilombo entre uma interpretação literal advinda da arqueologia, que identifica vestígios materiais, ou da antropologia, que valoriza a transmissão dos modos de criar, fazer e viver. 0 segundo problema é operacional e gira em torno do Decreto-Lei $n^{\circ}$ 25/1937 (Lei Brasileira do Tombamento), que mostra graves inadequações para esse tipo específico de Tombamento. As dúvidas expostas fazem com que esse artigo, escrito a partir do método dedutivo de investigação, sobre normas, jurisprudência e doutrina, tenha por objetivo averiguar a hipótese sobre uma natureza jurídica especial do Tombamento em apreço, o que é confirmado ao cabo da investigação.
\end{abstract}

Palavras-chave: Constituição; Extraordinário; Quilombo; Utilidade Pública; Tombamento.

\begin{abstract}
The article 216, paragraph 5 of the Brazilian Constitution establishes the registration of documents and sites containing traces of the ancient Quilombos. However, the fulfillment of this norm is threatened for two main reasons: the first one involves the theoretical discussion materialized in the doubt about the understanding of what is Quilombo, that oscillates of a literal interpretation coming from the archeology, which identifies material vestiges, or from the anthropology, which values the transmission of the ways of creating, doing and living. The second problem is operational and revolves around Decree Law no. 25/1937 (Brazilian Law of Heritage Listing), which would show serious inadequacies for this specific type of heritage listing. The above doubts lead this article, written from the deductive method of investigation, done on norms, jurisprudence and doctrine, to investigate the hypothesis about a special legal nature of this heritage listing, which is confirmed at the end of the investigation.
\end{abstract}

Keywords: Constitution; Extraordinary; Quilombo; Public utility; Heritage listing.

\section{RESUMEN}

El artículo 216, $\S 5^{\circ}$ de la Constitución de Brasil determina el Tombamento de documentos y sitios que contengan vestigios de los antiguos Quilombos. Sin embargo, el cumplimiento de esta norma está amenazado, por dos motivos principales: el primero involucra la discusión teórica materializada en la duda sobre el entendimiento de lo que es 
Quilombo, que oscila de una interpretación literal proveniente de la arqueología (por identificar vestigios materiales), hasta una de la antropología (por valorizar la transmisión de los modos de crear, hacer y vivir). El segundo problema es operacional y gira en torno al Decreto-Ley $n^{\circ}$ 25/1937 (Ley Brasileña del Tombamento), que mostraría graves inadecuaciones para ese tipo específico de Tombamento. Las dudas expuestas, hacen que este artículo, escrito a partir del método deductivo de investigación, hecho sobre normas, jurisprudencia y doctrina, objetive averiguar la hipótesis sobre una naturaleza jurídica especial de este Tombamento, lo que es confirmado al cabo de la investigación.

Palabras clave: Constitución; Extraordinário; Quilombo; Utilidad Pública; Tombamento.

\section{SUMÁRIO}

INTRODUÇAO; 1 PASSADO E PRESENTE DE RESISTÊNCIAS; 2 O CONTEXTO CONSTITUINTE DE 1987/1988 E $O$ ARTIGO 216, \$5; 3 A PERSPECTIVA DA COMUNIDADE QUILOMBOLA; 4 TOMBAMENTO OU REGISTRO; 5 A NATUREZA EXTRAORDINÁRIA DO TOMBAMENTO DOS ANTIGOS QUILOMBOS; CONCLUSÃO; REFERÊNCIAS.

\section{INTRODUÇÃO}

0 presente estudo analisa o artigo 216 , $\S 5^{\circ}$ da Constituição Federal de 1988, que de forma taxativa prevê a possibilidade de o Estado tombar documentos e sítios onde existiram antigos Quilombos. Sob a responsabilidade do Instituto do Patrimônio Histórico e Artístico Nacional (IPHAN), a eficácia do preceito constitucional vem sendo comprometida em razão de divergências quanto a aspectos de materialidade e temporalidade que resultam em dúvidas do que seria ou deveria ser enquadrado como Quilombo e sua consequente proteção estatal.

Ocorre que, independente dessas questões, há a determinação constitucional que, juntamente com o artigo 68 do Ato das Disposições Constitucionais Transitórias (ADCT), refere-se diretamente ao passado histórico afro-brasileiro que fora construído sob uma perspectiva de luta e resistência, o que por si só já exige uma visão diferente da adotada no país, que tradicionalmente prioriza a ligação com o continente europeu.

Ao determinar a proteção por tombamento, o artigo 216 , $\S 5^{\circ}$, traz outro pertinente questionamento: a aplicabilidade ou não do Decreto-Lei $n^{\circ} 25 / 1937,{ }^{1}$ que rege a figura do tombamento desde a terceira década do século XX. Dessa forma, pretende-se analisar o conceito de Quilombo e a necessidade de sua intepretação diferente da adotada até o momento, tendo como base os parâmetros da própria Constituição Federal (CF), objetivando dessa forma

\footnotetext{
${ }^{1}$ BRASIL. Decreto-lei $n^{\circ} 25$, de 30 de novembro de 1937. Organiza a proteção do patrimônio histórico e artístico nacional. Lex, Rio de Janeiro, DF, 1937. Disponível em: http://www6.senado.gov.br/legislacao/ListaTextolntegral.action?id=76419\&norma=10315. Acesso em: 19 out. 2017.
} 
ISSN 1981-3694

(DOI): $10.5902 / 1981369430750$

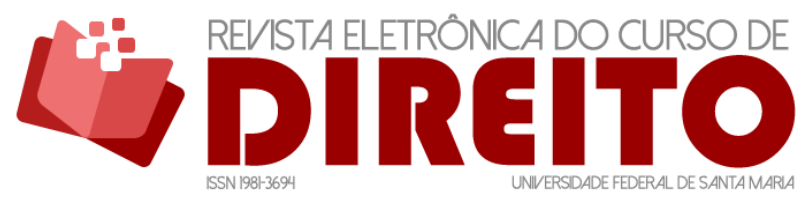

A NATUREZA JURÍDICA EXTRAORDINÁRIA DO TOMBAMENTO DOS ANTIGOS QUILOMBOS

FRANCISCO HUMBERTO CUNHA FILHO PAULO SÉRgIO FREIRE NOGUEIRA

averiguar a hipótese de que este específico tombamento deva ter caráter jurídico extraordinário, distinto, portanto, do procedimento previsto no mencionado Decreto-Lei, a fim de que possa ser operacionalizado, dadas as suas peculiaridades, que serão evidenciadas ao longo do texto.

No primeiro tópico, faz-se um panorama sobre a necessidade de avalizar o histórico do negro no Brasil sob a perspectiva antropológica de etnicidade, levando-se em consideração elementos como resistência e exclusão. Dando sequência, aborda-se no segundo tópico o contexto de formulação do artigo 216 da Constituição Federal no âmbito da Assembleia Nacional Constituinte de 1988 e a dificuldade, até mesmo dos próprios movimentos sociais, de apresentarem, à época, reivindicações de forma inovadora, a fim de garantir proteção efetiva do patrimônio cultural negro no Brasil.

Nos tópicos seguintes, faz-se um estudo a partir de uma visão antropológica contemporânea sobre "tombamento de comunidade", inserido em uma perspectiva de diferença histórica do negro no Brasil. Analisa-se ainda o tombamento como o instituto escolhido pela Carta Magna para as protetivas da cultura negra no país, no que concerne à memória material dos Quilombos, não se confundindo com patrimônio imaterial, em paralelo com a extraordinariedade desse tipo de tombamento.

Arremata-se assim um contexto no qual seja possível colaborar com o desafio exigido pelo legislador constitucional brasileiro no que se refere ao tombamento das antigas comunidades Quilombolas.

\section{PASSADO E PRESENTE DE RESISÊNCIA}

A Constituição Federal, promulgada em 1988, é sem dúvida um marco no campo do Direito Constitucional Brasileiro, sobretudo no que concerne à inserção e à ampliação de garantias e proteções a grupos minoritários existentes no país que, historicamente, foram deixados à margem das políticas protetivas encabeçadas pela sociedade de uma forma geral. Povos indígenas e afrodescendentes foram contemplados com um texto constitucional que, se não é o ideal, definitivamente é um meio, se bem utilizado, a prover cidadania destes grupos.

Atenta-se, então, ao caso dos afrodescendentes, que em seu passado colonial serviram de moeda para portugueses. Seus descendentes, tempo depois, protagonizarem um intenso comércio destas pessoas oriundas da África para o Brasil, a fim de fomentar a economia agrícola, utilizando-os como mão de obra. Assim, seja no Brasil Colônia ou no Brasil Império, o cotidiano 
negro se deu em prol de um único objetivo, que era o da servidão forçada. A liberdade, nesse caso, era uma utopia só alcançada no nível estritamente jurídico com a abolição da escravatura, ocorrida no Brasil Império entre os anos de 1850 a 1888 com a assinatura da Lei Áurea, último ato normativo nessa empreitada.

Um exemplo de resistência negra nesse período - que, embora em um outro contexto, perdura até hoje - foram os chamados Quilombos. Nascidos das mãos de negros escravos fugidos de fazendas brasileiras, os Quilombos tornaram-se um símbolo de resistência negra contra a opressão dos escravocratas da sociedade colonial. Eram comunidades muitas vezes distantes do litoral (local onde se concentrava a maior parte da população do país), formadas essencialmente por negros fugitivos. Entre tantos Quilombos que se destacaram, está o Quilombo dos Palmares, localizado em um rincão do Nordeste Brasileiro e liderado por um dos personagens mais emblemáticos da história negra no Brasil, Zumbi dos Palmares:

O Quilombo dos Palmares está localizado no município de União dos Palmares, foi inscrito no Livro do Tombo Arqueológico, Etnográfico e Histórico, em 1986. Entre os séculos XVII e XVIII, negros, brancos e índios organizaram a República dos Palmares. Começou a constituir-se em 1630, durante o período de lutas contra os holandeses e da economia canavieira. No século XVIII, estabeleceu-se na Serra da Barriga o Quilombo dos Macacos, sede do Quilombo dos Palmares. O governador eleito e vitalício, Zumbi, e seu comando superior residiam na capital, a Cidade Real dos Macacos, atual União dos Palmares. A população total chegou a 30.000 pessoas, agrupadas em povoados. Em torno de cada um deles existia uma área de agricultura e pecuária onde todos trabalhavam. Não podendo lutar contra o Exército e suas armas bélicas, os quilombolas palmarinos foram exterminados em 14 de maio de 1697. Ainda se conservam, nas proximidades da Serra, as últimas pedras das trincheiras onde se abrigaram durante a luta. ${ }^{2}$

Esse passado de lutas da comunidade afrodescendente se fez valer no texto constitucional de 1988. Entre os artigos com referência direta a essas comunidades, estão o artigo 68, do Ato das Disposições Constitucionais Transitórias (ADCT) e o artigo 216, § $5^{\circ}$ da Constituição Federal. 0 primeiro garante a propriedade definitiva da terra aos remanescentes das comunidades Quilombolas, e o segundo obriga o Estado a proteger, através do instituto do Tombamento, "documentos e os sítios detentores de reminiscências históricas dos antigos Quilombos."3

2 IPHAN. Bens arqueológicos tombados. Disponível em: http://portal.iphan.gov.br/cna/pagina/ detalhes/895/. Acesso em: 28 out. 2017.

${ }^{3}$ MORAES, Alexandre de. Constituição da República Federativa do Brasil: de 5 de outubro de 1988. 41. ed. São Paulo: Atlas, 2015. p. 227. 
A responsabilidade pela eficácia desses artigos, atualmente, recai sobre duas autarquias e uma fundação. Com relação à propriedade da terra, o Instituto de Colonização e Reforma Agrária (INCRA), juntamente com a Fundação Cultural Palmares, tem a incumbência da emissão desses títulos (Decreto $\left.\mathrm{n}^{\circ} 4.887 / 2003\right)^{4}$ e, utilizando-se de regulamentação prevista na Instrução Normativa $n^{0} 56 / 2009 /$ INCRA, ${ }^{5}$ define os parâmetros do que seria remanescente dos Quilombos. Os títulos são obtidos através da produção de um Relatório Técnico de Identificação e Demarcação (RTID). Diz o artigo 68 do ADCT que: “Aos remanescentes das comunidades dos quilombos que estejam ocupando suas terras é reconhecida a propriedade definitiva, devendo o Estado emitir-lhes os títulos respectivos." 6

0 termo remanescente utilizado no texto do artigo 68 do ADCT gerou controvérsias, pois é cediço que remanescente seria o que tinha restado de tal coisa. Esse significado literal tornaria difícil a emissão de propriedade de terra para as comunidades Quilombolas atuais e a consequente ineficácia do artigo.

Os vestígios físicos do que teria sido uma antiga comunidade colonial, muitas vezes miserável, escondida e à mercê de uma permanente invasão por parte de coronéis daquele período, como foram os antigos Quilombos, não seria capaz de possuir meios físicos (materialmente) de perdurar ao longo dos tempos. Corrobora com esse entendimento a descrição da vida material e econômica feita por Gomes, na qual deixa evidente que a grande maioria dos bens produzidos era feita a partir de material perecível, literalmente:

Com galhos e folhas e troncos fabricavam artefatos como cachimbos, cestos, canoas e cordas. Tinham criações de animais como galinhas, patos e porcos. Há informações de que existiam olarias em Palmares. Seus habitantes produziam cerâmica e outros objetos em barro [...] tinham sua própria metalurgia. Fabricavam-se lanças, flechas, facões, foices, enxadas e outros artefatos. ${ }^{7}$

\footnotetext{
4 BRASIL. Decreto $\mathrm{n}^{\circ}$ 4.887, de 20 de novembro de 2003. Regulamenta o procedimento para identificação, reconhecimento, delimitação, demarcação e titulação das terras ocupadas por remanescentes das comunidades dos quilombos de que trata o art. 68 do Ato das Disposições Constitucionais Transitórias. Presidência da República, Brasília, DF, 2003. Disponível em: http://www.planalto.gov.br/ccivil_03/decreto/2003/D4887.htm. Acesso em: 28 out. 2017.

5 BRASIL. Instrução Normativa $n^{\circ} 56$, de 7 de outubro de 2009. Regulamenta o procedimento para identificação, reconhecimento, delimitação, demarcação, desintrusão, titulação e registro das terras ocupadas por remanescentes das comunidades dos quilombos de que tratam o Art. 68 do Ato das Disposições Constitucionais Transitórias da Constituição Federal de 1988 e o Decreto $\mathrm{n}^{\circ} 4.887$, de 20 de novembro de 2003. Diário Oficial da União, Brasília, DF, 9 out. 2010. Seção 1, p. 149-150. ${ }^{6}$ BRASIL. Instrução Normativa $n^{\circ} 56$, de 7 de outubro de 2009. Regulamenta o procedimento para identificação, reconhecimento, delimitação, demarcação, desintrusão, titulação e registro das terras ocupadas por remanescentes das comunidades dos quilombos de que tratam o Art. 68 do Ato das Disposições Constitucionais Transitórias da Constituição Federal de 1988 e o Decreto $n^{\circ} 4.887$, de 20 de novembro de 2003. Diário Oficial da União, Brasília, DF, 9 out. 2010. Seção 1, p. 149-150. ${ }^{7}$ GOMES, Flávio. Palmares: escravidão e liberdade no Atlântico Sul. São Paulo: Contexto, 2005. p. 77.
} 
Em tal contexto, é aceitável que restem de lembrança e referência apenas as tradições de seus próprios habitantes, seus costumes e crenças, passados de geração em geração.

Dessa forma, a fim de garantir a eficácia desse artigo, utilizou-se de uma hermenêutica mais ampla sobre o significado da palavra e o que ela representa no contexto trazido pelo artigo 68 (ADCT), dando-se uma visão antropológica ao termo: “[...] onde se lê remanescente, entenda-se descendente, que significa derivar, provir por geração. Destarte, devemos estender o conceito de comunidade quilombola como sendo descendentes de quilombos. Só assim obteremos efetividade do comando constitucional." 8

Essa visão, inspirada na antropologia, impregnou a formação do texto constitucional de 1988, sobretudo nos aspectos de disciplinamento dos direitos culturais no que atine ao dimensionamento do patrimônio cultural e do seu instrumental protetivo

[...] nota-se também que foi esclarecido o critério para a proteção; antes, exigia-se que 0 bem se vinculasse à história, etnografia, arqueologia, paisagística, arte ou bibliografia, passando, com a Constituição, para o aspecto mais universalizante de simplesmente "portar referência à identidade, à ação, à memória dos diferentes grupos formadores da sociedade brasileira. ${ }^{9}$

Com isso, deveria sair de cena uma visão puramente colonial/material/arqueológica (quando se refere a remanescente em sentido restrito) para um sentido de etnicidade, termo associado por Bobbio et al. como um sentido de "falar a mesma língua, estar radicado no mesmo ambiente humano e no mesmo território, possuir as mesmas tradições são fatores que constituem a base fundamental das relações ordinárias da vida cotidiana”. ${ }^{10}$ Mais à frente, ainda sobre essa definição, Bobbio concluiu: “[...] as relações sociais que derivam do fato de pertencer a mesma etnia criam interesses coletivos e vínculos de solidariedade caracteristicamente comunitários."11 Com essa perspectiva de etnicidade aliada a um entendimento ampliado do que seria remanescente, envolvendo ainda historicidade, relação com o meio ambiente, meios de produção e dados gerais (requisitos previstos no art. 10 da

8 GAMA, Alcides Moreira da. 0 direito de propriedade das terras ocupadas pelas comunidades descendentes de quilombos. 2010. Disponível em: http://www.palmares.gov.br/wpcontent/uploads/2010/11/0-direito-de-propriedade-das-terras-ocupadas-pelas.pdf. Acesso em: 19 out. 2017. p. 2.

${ }^{9}$ CUNHA FILHO, Francisco. Impacto da Constituição Federal de 1988 sobre o tombamento de bens do patrimônio cultural brasiliero. In: ENECULT - ENCONTROS DOS ESTUDOS MULTIDISCPLINARES EM CULTURA, 4., 2008, Salvador. Anais eletrônicos [...] Salvador: Ufba, 2008. p. 1-15. Disponível em: http://www.cult.ufba.br/enecult2008/14209-02.pdf. Acesso em: 20 ago. 2017. p. 4.

${ }^{10}$ BOBBIO, Norberto et al. Dicionário de Política. São Paulo: Imprensa Oficial, 2000. p. 249.

11 BOBBIO, Norberto et al. Dicionário de Política. São Paulo: Imprensa Oficial, 2000. p. 249. 
Instrução Normativa INCRA n ${ }^{\circ}$ 56/2009), ${ }^{12}$ chega-se à concepção jurídico-normativa atual. Com isso, foi possível ao Estado englobar grupos de afrodescendentes que viviam e vivem marginalizados em terras passíveis de questões judiciais envolvendo, não raro, latifundiários.

No que se refere ao artigo $216, \S 5^{\circ}$ da Constituição Federal, cabe ao Instituto do Patrimônio Histórico e Artístico Nacional (IPHAN), a responsabilidade de tombar sítios com valor histórico que abarquem a linha do tempo da resistência negra contra as políticas opressoras pelas quais este grupamento humano se viu envolvido. 0 texto trazido pelo artigo, no seu caput e no parágrafo $5^{\circ}$, diz o seguinte:

Art. 216. Constituem patrimônio cultural brasileiro os bens de natureza material e imaterial, tomados individualmente ou em conjunto, portadores de referência à identidade, à ação, à memória dos diferentes grupos formadores da sociedade brasileira, nos quais se incluem:[...] $\S 5^{\circ}$ Ficam tombados todos os documentos $\mathrm{e}$ os sítios detentores de reminiscências históricas dos antigos quilombos. ${ }^{13}$

Mais uma vez, frisa-se aqui a preocupação do legislador com a inclusão de grupos alheios à proteção ao longo de muitos anos de história brasileira. No entanto, no que se refere ao que se tem aplicado sobre esse artigo, o IPHAN tem sido conservador na interpretação de seus objetivos.

Segundo Vaz, ${ }^{14}$ um documento interno ligado ao IPHAN (parecer $n^{\circ} 47$ ) de 1998 restringe o órgão a reconhecer como "sítios detentores de reminiscências históricas" apenas aqueles onde efetivamente foram encontrados objetos dos antigos Quilombos. Assume-se assim uma perspectiva puramente arqueológica, o que, para o contexto negro, traduz-se em dificuldade de revelar seu passado. Rossano Lopes Bastos explica:

O registro arqueológico sempre terá dificuldades em expressar a realidade passada. Estamos mais interessados em compor um cenário em que todos os atores estejam contemplados com diferentes formas de entender o mundo ou,

12 BRASIL. Instrução Normativa $n^{\circ} 56$, de 7 de outubro de 2009. Regulamenta o procedimento para identificação, reconhecimento, delimitação, demarcação, desintrusão, titulação e registro das terras ocupadas por remanescentes das comunidades dos quilombos de que tratam o Art. 68 do Ato das Disposições Constitucionais Transitórias da Constituição Federal de 1988 e o Decreto $\mathrm{n}^{\circ} 4.887$, de 20 de novembro de 2003. Diário Oficial da União, Brasília, DF, 9 out. 2010. Seção 1, p. 149-150.

${ }^{13}$ MORAES, Alexandre de. Constituição da República Federativa do Brasil: de 5 de outubro de 1988. 41. ed. São Paulo: Atlas, 2015. p. 227.

14 VAZ, Beatriz Accioly. Quilombos. In: GRIECO, Bettina; TEIXEIRA, Luciano; THOMPSON, Analucia (Org.). Dicionário IPHAN de Patrimônio Cultural. 2. ed. Rio de Janeiro: IPHAN, 2016. Disponível em: http://portal.iphan.gov.br/dicionarioPatrimonioCultural/detalhes/81/quilombo. Acesso em: 28 out. 2017. 
pelo menos, tentar exercitar uma arqueologia, uma história, uma antropologia, um direito que saia do pragmatismo das narrativas dos conquistadores. ${ }^{15}$

Um outro argumento do IPHAN utilizado para negar o tombamento de remanescentes de Quilombos é "a percepção de que nesses contextos a preservação de uma estrutura material poderia contrariar a dinamicidade do espaço e do grupo que ali vive." ${ }^{16}$ Curiosamente, se tomarmos por base restritivamente apenas a proteção do patrimônio cultural material, é possível observar sua aplicação de forma inconteste em diversos centros urbanos brasileiros, onde existem modificações diárias do espaço, uma vez que estamos nos referindo a núcleos urbanos em plena atividade. Dados do IPHAN ${ }^{17}$ revelam que se encontram tombados no Brasil até o mês de janeiro de 2017: “[...] 87 conjuntos urbanos protegidos, sendo 67 tombados, três tombamentos provisórios, 14 rerratificações, um tombamento emergencial, dois anexados (destes dois, um tombado e um tombamento provisório)."

Como já dito, Quilombos sempre foram comunidades de resistência, independente da época. No período colonial, eram locais de difícil acesso, longe das cidades e que viviam sob a iminência de invasão por parte dos coronéis em busca de suas propriedades, no caso, os negros fugitivos. Ou seja, suas construções eram frágeis, bem como seus utensílios. 0 reflexo disso é o quase inexistente tombamento desse tipo feito pelo IPHAN. "É sintomático que, além da Serra da Barriga, tombada em 1986 como homenagem ao Quilombo dos Palmares [...], o outro tombamento relacionado aos quilombos tenha sido o do Quilombo do Ambrósio."18

A saída para esse entrave estaria agora no que preceitua o artigo 68 do ADCT, que ampliou juridicamente os conceitos trazidos naquele texto, cujo objetivo é de "contemplar as comunidades negras cujas formações são particulares e adversas e que se auto reconheçam como uma comunidade tradicional e preservam em suas práticas cotidianas, a memória de seus antepassados escravizados no Brasil."19

15 BASTOS, Rossano Lopes. Patrimônio, Memória, Direito Cultural e Território. In: NASCIMENTO, João Carlos Nogueira et al. (Org.). Patrimônio cultural, territórios e identidades. Florianópolis: Atilênde, 2012. p. 85-104. p. 100.

${ }^{16}$ VAZ, Beatriz Accioly. Quilombos. In: GRIECO, Bettina; TEIXEIRA, Luciano; THOMPSON, Analucia (Org.). Dicionário IPHAN de Patrimônio Cultural. 2. ed. Rio de Janeiro: IPHAN, 2016. Disponível em: http://portal.iphan.gov.br/dicionarioPatrimonioCultural/detalhes/81/quilombo. Acesso em: 28 out. 2017. 17 IPHAN. Conjuntos Urbanos Tombados (Cidades Históricas). Disponível em: http://portal.iphan.gov.br/pagina/detalhes/123. Acesso em: 28 out. 2017.

18 VAZ, Beatriz Accioly. Quilombos. In: GRIECO, Bettina; TEIXEIRA, Luciano; THOMPSON, Analucia (Org.). Dicionário IPHAN de Patrimônio Cultural. 2. ed. Rio de Janeiro: IPHAN, 2016. Disponível em: http://portal.iphan.gov.br/dicionarioPatrimonioCultural/detalhes/81/quilombo. Acesso em: 28 out. 2017. 19 FELIPE, Delton Aparecido. Patrimônio Cultural Negro no Paraná: A comunidade Quilombola Paiol de Telha. In: CONGRESSO INTERNACIONAL DE HISTÓRIA, 7., 2015, Maringa. Anais eletrônicos [...] Maringa: 
Ou seja, ampliando-se a visão sobre o conceito de Quilombo no referido dispositivo, obteve-se uma inserção eficaz de garantia de propriedade a uma população historicamente marginalizada. Inclusive, tais comunidades são centros de tradições e manifestações culturais curiosamente abarcadas pela protetiva do bem cultural imaterial, dentre eles, cita Beatriz Vaz, ${ }^{20}$ “[... ] o Jongo no Sudeste, o Samba de Roda do Recôncavo Baiano, o Complexo Cultural do Bumba-meu-Boi do Maranhão. Além disso, já foram realizados vários inventários culturais de comunidades quilombolas", sendo pertinente notar que essa riqueza imaterial dos Quilombos contrasta com a dificuldade de proteger culturalmente aquele modo de vida fomentador de outros bens culturais de valor imensurável, presente há séculos.

Portanto, estas comunidades, embora não sejam possuidoras de vestígios materiais claros dos antigos Quilombos, possuem de forma concreta em seu modo de vida cotidiano um exemplo claro de reminiscências das culturas de seus antepassados, transmitidas de geração em geração, não havendo, assim, razão para ignorar tal contexto no âmbito do artigo 216 , § $5^{\circ}$ da Constituição.

\section{O CONTEXTO CONSTITUINTE DE 1987/1988 E O ARTIGO 216, $\$ 5^{\circ}$}

Para compreender a visão sobre os artigos referentes às comunidades Quilombolas, fazse necessário entender o contexto em que foram feitos, analisando-se as posições adotadas na Assembleia Nacional Constituinte (ANC) de 1987/1988.

Uma das primeiras dificuldades foi a reorganização dos movimentos sociais em prol de uma agenda que garantisse um processo constituinte eficaz, no que diz respeito a uma sociedade brasileira inclusiva e protetiva. Essa expectativa tornava-se mais engajadora, pois esses grupos, ditos minoritários, eram-no na política dominante do país, mas não no cotidiano brasileiro, e tinham naquele momento a possibilidade de defender suas bandeiras.

Outro ponto que moldou, mesmo que indiretamente, os futuros artigos constitucionais, foi a chamada Comissão Afonso Arinos. Tratava-se de uma comissão formada por diversos intelectuais da elite brasileira da época e tinha em seu corpo uma formação bastante heterogênea sob o aspecto ideológico. Esta comissão foi convocada pelo então presidente da

Uem, 2015. p. 3303 - 3315. Disponível em: http://www.cih.uem.br/anais/2015/trabalhos/1236.pdf. Acesso em: 19 out. 2017. p. 3305.

${ }^{20}$ VAZ, Beatriz Accioly. Quilombos. In: GRIECO, Bettina; TEIXEIRA, Luciano; THOMPSON, Analucia (Org.). Dicionário IPHAN de Patrimônio Cultural. 2. ed. Rio de Janeiro: IPHAN, 2016. Disponível em: http://portal.iphan.gov.br/dicionarioPatrimonioCultural/detalhes/81/quilombo. Acesso em: 28 out. 2017. 
República, José Sarney e, constituída por notáveis, produziu um anteprojeto de constituição que deveria servir como ponto de partida para as discussões que se sucederiam após a instalação oficial da Assembleia Constituinte de $87 / 88$. Esse texto, no entanto, não foi enviado de forma oficial à ANC, sob a alegação de que tal medida tomada pelo Executivo seria interpretada como uma usurpação de competência do Legislativo, principalmente levando-se em conta o processo de redemocratização que o país passava.

Entre as diversas subcomissões criadas no Congresso Nacional para a formulação de propostas para o texto constitucional de 1988, duas se destacaram a discutir questões relativas à comunidade negra, quais sejam: a Subcomissão dos Negros, Populações Indígenas, Pessoas Deficientes e Minorias e a Subcomissão de Educação, Cultura e Esportes, que tratava do tema Cultura na ANC e foi a responsável por grande parte do atual artigo 216 da CF. ${ }^{21}$

Consubstanciada em documentos propositivos feitos pelo Centro de Estudos AfroBrasileiros (CEAB), a Subcomissão de Educação, Cultura e Esportes pouco avançou em ineditismo ou em uma perspectiva diferenciada para proteção cultural do negro:

[...] pouco se viu reivindicações efetivas e diretas ao patrimônio cultural. A mediação de documentos elaborados por técnicos baseou também essas proposições. Para ficar em um exemplo, a última proposição é idêntica àquilo proposto pela Comissão Afonso Arinos [...] não há nenhuma referência literal ao negro. 22

Assim percebem-se, especificamente no tocante à comunidade negra, influências da chamada Comissão de Notáveis em proposições que tratam diretamente do interesse afrodescendente brasileiro e pouca diferenciação no trato com a cultura e história afrobrasileira.

Originalmente, o artigo 216 , $\S 5^{\circ}$, e o artigo 68 do ADCT compunham um só texto. ${ }^{23}$ No entanto, durante a ANC, existiu uma desvinculação do social (previsto no artigo 68 do ADCT no tocante ao direito de propriedade dado aos Quilombolas) e da proteção cultural, revestida no modelo do tombamento, que passou a compor um parágrafo do artigo 216 da CF. Yussef Daibert Salomão de Campos fala das consequências de tal cisão:

${ }^{21}$ CAMPOS, Yussef Daibert Salomão de. A dimensão política do patrimônio cultural na constituinte de 1987 - 1988. 2015. 242 f. Tese (Doutorado) - Curso de História, Instituto de Ciências Humanos, Universidade Federal de Juiz de Fora, Juiz de Fora, 2015. p. 86.

22 CAMPOS, Yussef Daibert Salomão de. A dimensão política do patrimônio cultural na constituinte de 1987 - 1988. 2015. 242 f. Tese (Doutorado) - Curso de História, Instituto de Ciências Humanos, Universidade Federal de Juiz de Fora, Juiz de Fora, 2015. p. 105.

${ }^{23}$ CAMPOS, Yussef Daibert Salomão de. A dimensão política do patrimônio cultural na constituinte de 1987 - 1988. 2015. 242 f. Tese (Doutorado) - Curso de História, Instituto de Ciências Humanos, Universidade Federal de Juiz de Fora, Juiz de Fora, 2015. p. 109. 
O reconhecimento do quilombo, seu tombamento e a emissão do título de propriedade poderiam ser considerados o mais importante passo dado pelo negro e pela Constituinte na caminhada pela desconstrução da desigualdade no país. Contudo, a divisão em artigos distintos - o 67 do ADCT e o $\$ 5^{\circ}$ do artigo 216 diminuíram a importância política do possível avanço, bem como implicaram em pluralidade de interpretações jurídicas sobre seus efeitos. ${ }^{24}$

Entre as diversas intepretações jurídicas ligadas a estes artigos, está o já citado significado da palavra "remanescentes" (Art. 68 do ADCT) ou "reminiscências" (Art. 216, § 5 CF). ${ }^{25}$ No entanto, passando a analisar apenas o artigo 216 e o $§ 5^{\circ}$, essa pluralidade vai além, a começar pela forma taxativa com que a Constituição Federal garante a proteção, através do instituto do tombamento, dos "documentos e das reminiscências dos antigos quilombos" e com isso se vê surgirem desdobramentos posteriores no que se refere à proteção deste patrimônio cultural.

\section{A PERSPECTIVA DA COMUNIDADE QUILOMBOLA}

Essa exigência constitucional obriga também a refletir sobre o Decreto-Lei $n^{\circ} 25 / 37$ que trata do tombamento, pois, embora recepcionado pela $\mathrm{CF} / 88$, o artigo $216, \S 5^{\circ}$ da própria $\mathrm{CF}$, pode ser interpretado como mais um exemplo de sua possível caducidade com relação aos parâmetros constitucionais instituídos. O próprio IPHAN, que até o momento não conseguiu de forma eficaz atender essa atribuição, já discute um modelo de tombamento que possa atender o contexto histórico negro no Brasil. Beatriz Accioly Vaz retrata essa discussão no âmbito daquela autarquia:

Em 2005 o advogado Guilherme Cruz Mendonça, no âmbito do Programa de Especialização em Patrimônio PEP/IPHAN, elaborou um trabalho a respeito de tal questão que sugeria a redação de uma lei específica que regulamentasse o tombamento dos quilombos, entendendo que esse não se equipararia ao tombamento conforme o Decreto-Lei $n^{\circ}$ 25/37. Posteriormente, o Departamento de Patrimônio Material e Fiscalização organizou em 2007 o Dossiê Quilombos, reunindo uma série de documentos como forma de subsidiar uma decisão por parte do Conselho Consultivo, a respeito de qual seria a ação do IPHAN com relação a essa temática. Essa medida não teve, até o presente, nenhum encaminhamento. Já em 2008, circulou internamente no IPHAN um texto escrito

${ }^{24}$ CAMPOS, Yussef Daibert Salomão de. A dimensão política do patrimônio cultural na constituinte de 1987 - 1988. 2015. 242 f. Tese (Doutorado) - Curso de História, Instituto de Ciências Humanos, Universidade Federal de Juiz de Fora, Juiz de Fora, 2015. p. 109.

${ }^{25}$ MORAES, Alexandre de. Constituição da República Federativa do Brasil: de 5 de outubro de 1988. 41. ed. São Paulo: Atlas, 2015. 
por Dalmo Vieira Filho, ex-diretor do Depam/IPHAN, em que se propunha um tratamento da questão do tombamento dos quilombos diverso do proposto no parecer Deprot $n^{\circ} 47 / 98$, ampliando, de certa maneira, a conceituação anterior. ${ }^{26}$

O Decreto-Lei $n^{\circ} 25 / 1937^{27}$ prevê em seu texto a existência de 04 (quatro) livros de tombo. São eles: tombo arqueológico, etnográfico e paisagístico, tombo histórico, tombo das belas artes e tombo das artes aplicadas. 0 tombamento de um bem gera efeitos restritivos de uso e alienabilidade. Os efeitos são para todos, ou seja, para entes públicos ou pessoas físicas e jurídicas de direito privado. Ao transpor para a realidade vista nos antigos Quilombos, percebese um grande desafio em estabelecer parâmetros objetivos de materialidade (exigidos no Decreto) sobre uma comunidade, especialmente considerando o contexto histórico negro de exclusão.

Não obstante citar sempre que o tombamento, da forma como conhecido, é um instituto criado em 1937, em um cenário de país agrário que tornava-se urbano, onde era desejável um retorno às origens portuguesas a fim de transmitir um sentimento de conectividade do Brasil com o resto do mundo - leia-se, com os países desenvolvidos. Segundo Luiz Carlos Diógenes Oliveira, “neste momento, o Brasil, ainda oligárquico, agrário-exportador, persegue o desejo de ingressar robustamente na vida urbana de molde industrial, sem perder o vínculo com o passado." 28 Percebe-se uma enorme distância do que se determina no artigo 216, § $5^{\circ}$ da CF 88 para as definições estabelecidas com o Decreto-Lei $n^{\circ} 25 / 37,{ }^{29}$ que naquela época tinha como claro objetivo a proteção de bens culturais ligados à matriz europeia, no caso, os portugueses.

Dessa forma, surge a necessidade de associar a regulamentação (do Decreto-Lei) ao texto constitucional do artigo $216, \S 5^{\circ}$, que, além da taxatividade trazida com o tombamento, traz ainda um aspecto temporal quando se refere a “antigos Quilombos”. A utilização dos parâmetros antropológicos contidos no artigo 68 do ADCT exigirá, no âmbito do artigo $216, \S 5^{\circ}$,

\footnotetext{
${ }^{26} \mathrm{VAZ}$, Beatriz Accioly. Quilombos. In: GRIECO, Bettina; TEIXEIRA, Luciano; THOMPSON, Analucia (Org.). Dicionário IPHAN de Patrimônio Cultural. 2. ed. Rio de Janeiro: IPHAN, 2016. Disponível em: http://portal.iphan.gov.br/dicionarioPatrimonioCultural/detalhes/81/quilombo. Acesso em: 28 out. 2017. ${ }^{27}$ BRASIL. Decreto-lei $n^{\circ} 25$, de 30 de novembro de 1937. Organiza a proteção do patrimônio histórico e artístico nacional. Lex, Rio de Janeiro, DF, 1937. Disponível em: http://www6.senado.gov.br/legislacao/ListaTextolntegral.action?id=76419\&norma=10315. Acesso em: 19 out. 2017.

28 OLIVEIRA, Luiz Carlos Diógenes. Leis de Tombamento dos estados da região centro-oeste do Brasil perante à cidadania cultural expressa na constituição federal de 1988. In: CUNHA FILHO, Francisco Humberto et al. Proteção do patrimônio cultural brasileiro por meio de tombamento: estudo crítico e comparado das legislações estaduais organizadas por regiões. Fortaleza: UFC, 2013. p. 85-103. p. 86.

${ }^{29}$ BRASIL. Decreto-lei $n^{\circ} 25$, de 30 de novembro de 1937. Organiza a proteção do patrimônio histórico e artístico nacional. Lex, Rio de Janeiro, DF, 1937. Disponível em: http://www6.senado.gov.br/legislacao/ListaTextolntegral.action?id=76419\&norma=10315. Acesso em: 19 out. 2017.
} 
mudanças até mesmo sobre o que seria tombamento, “[...] considerando que o tombamento é um instrumento legal que só pode ser usado em bens materiais, não tendo aplicação em relação a 'comunidades', a conceituação de ‘quilombos' adotada pelo decreto 4.887 - a auto definição das comunidades deve ser repensada", ${ }^{30}$ daí a ideia de extraordinariedade.

Ressalte-se ainda que, além do antigo Quilombo dos Palmares no Estado de Alagoas, a única comunidade Quilombola em que foi possível o tombamento, no caso o do Sítio Ambrósio em Minas Gerais, baseou-se no conceito arqueológico do termo, pois nesse local foram encontrados vestígios materiais e, dada sua excepcionalidade material, foi inscrito no livro dos tombos com base no seu valor histórico e arqueológico ${ }^{31}$ pelo IPHAN.

É sabido que a cultura negra não resume sua história a essas duas comunidades. Além disso, a visão adotada pelo IPHAN, utilizando-se puramente de critérios de arqueologia, não alcança os parâmetros de etnicidade e historicidade, especialmente ao se considerar os ensejos de construção da identidade afro-brasileira, "com a clara percepção de que os objetos a serem trabalhados na preservação da memória dos grupos que resistiram à escravidão eram diferentes, restava ao IPHAN definir como o assunto seria tratado no Instituto", ${ }^{32}$ situação semelhante e já definida no artigo 68 do ADCT, por exemplo.

Independente do parâmetro que se utilize, as definições de tombamento previstas no artigo 216, § $5^{\circ}$ da CF/88, trarão impactos e desdobramentos. Urge estabelecer medidas que possam ser compreendidas conforme o texto constitucional, abarcando um debate importantíssimo acerca do que seria propriamente Quilombos, que tipo de comunidade poderia ser enquadrada no que rege o artigo e os próprios valores de igualdade material previstos no texto constitucional de 1988.

\section{TOMBAMENTO OU REGISTRO}

Em 1988, o Brasil, jurídica e politicamente, deixava no passado o regime autoritário instituído pelos militares, promulgando sua nova Constituição com participação de uma Assembleia Nacional Constituinte (ANC), dentro de um regime novamente democrático. "A Constituição de 1988 deu grande ênfase e valor às questões culturais, ao tratar com vagar o

30 CASTRO, Adler Homero Fonseca de. Quilombos: comunidades e patrimônio. 2005. Disponível em: http://www.labjor.unicamp.br/patrimonio/materia.php?id=55. Acesso em: 19 out. 2017.

31 CASTRO, Adler Homero Fonseca de. Quilombos: comunidades e patrimônio. 2005. Disponível em: http:// www.labjor.unicamp.br/patrimonio/materia.php?id=55. Acesso em: 19 out. 2017.

32 CASTRO, Adler Homero Fonseca de. Quilombos: comunidades e patrimônio. 2005. Disponível em: http://www.labjor.unicamp.br/patrimonio/materia.php?id=55. Acesso em: 19 out. 2017. 
tema, ampliar as disposições normativas a ele concernentes, bem como instituir garantias em seu favor."33

Indo além, a Constituição de 1988 trouxe “uma dimensão multicultural, consagrada pela interação sociedade-Estado na realização das tarefas que promovam tanto o exercício desses direitos, como a proteção e fruição dos bens culturais."34 Observa-se, então, um tratamento amplo e contemporâneo da cultura e suas nuances com novos parâmetros e visões.

Os artigos 215 e 216 da Constituição de 1988, resumidamente, garantem de forma expressa o "pleno exercício dos direitos culturais" e proteção, por parte do Estado, das "manifestações das culturas populares, indígenas e afro-brasileiras", incluindo-se como patrimônio, antes apenas histórico-artístico e, agora, também cultural, "os bens de natureza material e imaterial." 350 texto ainda trouxe novas formas de proteção desse patrimônio, como inventários, registros, dentre outros mecanismos.

Em se tratando especificamente do registro, esta nova forma de proteção cultural "foi instituída porque há muito se havia percebido que o tombamento era inócuo para coisas intangíveis, uma vez que quando se adota este procedimento, o que se quer é uma perenização do aspecto do bem tombado pelo maior tempo possível." ${ }^{36} 0$ registro foi estabelecido em 2000 através do Decreto $n^{\circ} 3.551,{ }^{37}$ cabendo a esse instituto a proteção do patrimônio cultural imaterial.

Paralelo a essas novas formas de proteção, está o Decreto-Lei no 25 de $1937^{38}$, que trata do tombamento e que fora constituído há exatos oitenta anos, contados do ano em que o artigo foi redigido. O referido Decreto-Lei é um exemplo raro dentro do ordenamento jurídico

${ }^{33}$ CUNHA FILHO, Francisco Humberto et al. (Org.). Proteção do patrimônio cultural brasileiro por meio de tombamento: estudo crítico e comparado das legislações estaduais organizadas por regiões. Fortaleza: UFC, 2013. p. 11

34 SOARES, Inês Virginia Prado. Direito ao (do) Patrimônio Cultural Brasileiro. Belo Horizonte: Fórum, 2009. p. 106.

${ }^{35}$ MORAES, Alexandre de. Constituição da República Federativa do Brasil: de 5 de outubro de 1988. 41. ed. São Paulo: Atlas, 2015. p. 225-227.

36 CUNHA FILHO, Francisco. Impacto da Constituição Federal de 1988 sobre o tombamento de bens do patrimônio cultural brasiliero. In: ENECULT - ENCONTROS DOS ESTUDOS MULTIDISCPLINARES EM CULTURA, 4, 2008, Salvador. Anais eletrônicos [...] Salvador: Ufba, 2008. p. 1-15. Disponível em: http://www.cult.ufba.br/enecult2008/14209-02.pdf. Acesso em: 20 ago. 2017. p. 4.

37 BRASIL. Decreto $n^{\circ} 3.551$, de 4 de agosto de 2000. Institui o Registro de Bens Culturais de Natureza Imaterial que constituem patrimônio cultural brasileiro, cria o Programa Nacional do Patrimônio Imaterial e dá outras providências. Presidência da República, Brasília, DF, 2000. Disponível em: https://www.planalto.gov.br/ccivil_03/decreto/d3551.htm. Acesso em: 28 out. 2017.

${ }^{38}$ BRASIL. Decreto-lei $\mathrm{n}^{\circ} 25$, de 30 de novembro de 1937. Organiza a proteção do patrimônio histórico e artístico nacional. Lex, Rio de Janeiro, DF, 1937. Disponível em: http://www6.senado.gov.br/legislacao/ListaTextolntegral.action?id=76419\&norma=10315. Acesso em: 19 out. 2017. 
brasileiro, no que diz respeito à longevidade. Com o novo texto constitucional, não houve revogação, vigendo plenamente com outros instrumentos; mas, "independentemente destas novas formas protetivas, o tombamento foi conservado, porém, baseado nos novos fundamentos [...] estas mudanças só muito lentamente vêm sendo percebidas"39 e acabam por revelar carências existentes no teor da norma varguista com relação a uma visão atualizada sobre tombamento, como será possível observar a partir do contexto englobado pelo artigo 216 da CF.

Tomando por base as duas formas de proteção do patrimônio cultural citadas (registro e tombamento), passa-se então a avaliar o que diz o artigo 216, $\S 5^{\circ} \mathrm{da} \mathrm{CF} / 88$. Em um primeiro momento, consubstanciada numa visão antropológica adotada pelo artigo 68 do ADCT, a palavra “reminiscências" poderia significar que "os sítios detentores de reminiscências históricas dos antigos quilombos" pudessem tomar uma linha protetiva de cunho imaterial e, nesse caso, as comunidades seriam hipoteticamente registradas como bens culturais imateriais, haja vista que o Decreto $\mathrm{n}^{\circ} 3.551 / 2000^{40}$ determina o registro de bens culturais de natureza imaterial (através de livros) com base em: saberes, celebrações, formas de expressão e lugares (artigo $1^{\circ}, \$ 1^{\circ}$ incisos I, II, III, IV). Há ainda a possibilidade de abertura de outros livros para registro de bens culturais imateriais que não se enquadrem nos itens citados acima.

É bem verdade que o uso de outro termo, sem referência ao meio de proteção (tombamento), a ser adotado com relação aos antigos Quilombos, poderia hipoteticamente permitir com uma proteção mais elástica, com maior facilidade de aplicação, haja vista o contexto histórico negro no Brasil ter sido construído dentro de uma perspectiva bastante diferente da de patrimônio cultural material deixado pelos portugueses, como já citado.

Ocorre que o texto constitucional é taxativo ao afirmar que: "Ficam tombados todos os documentos e os sítios detentores de reminiscências históricas dos antigos quilombos." ${ }^{41}$ Resta clara, por uma interpretação estritamente literal, a materialidade exigida no artigo para a aplicação da proteção, inviabilizando, prima facie, um entendimento imaterial no sentido de proteção às comunidades de uma forma geral.

${ }^{39}$ CUNHA FILHO, Francisco Humberto et al. (Org.). Proteção do patrimônio cultural brasileiro por meio de tombamento: estudo crítico e comparado das legislações estaduais organizadas por regiões. Fortaleza: UFC, 2013. p. 11.

${ }^{40}$ BRASIL. Decreto $n^{\circ} 3.551$, de 4 de agosto de 2000. Institui o Registro de Bens Culturais de Natureza Imaterial que constituem patrimônio cultural brasileiro, cria o Programa Nacional do Patrimônio Imaterial e dá outras providências. Presidência da República, Brasília, DF, 2000. Disponível em: https://www.planalto.gov.br/ccivil_03/decreto/d3551.htm. Acesso em: 28 out. 2017.

${ }^{41}$ MORAES, Alexandre de. Constituição da República Federativa do Brasil: de 5 de outubro de 1988. 41. ed. São Paulo: Atlas, 2015. p. 227. 
Sob este prisma, é oportuno ressaltar as palavras do Ministro Barroso: ${ }^{42}$ "os princípios constitucionais, portanto, explícitos ou não, passam a ser a síntese dos valores abrigados no ordenamento jurídico. Eles espelham a ideologia da sociedade, seus postulados básicos, seus fins". Acrescente-se a estas palavras a vontade do constituinte, definidas por Canotilho ${ }^{43}$, "o poder constituinte se revela sempre como uma questão de "poder", de "força" ou de "autoridade" política que está em condições de, numa determinada situação concreta, criar, garantir ou eliminar".

Ou seja, "estabelece o texto constitucional que, sem intermediação de lei, o adota em seu próprio texto para determinar que 'ficam tombados todos os documentos e os sítios detentores de reminiscências históricas dos antigos quilombos'" ${ }^{44}$, assim optou-se claramente pela diretriz via Constituição de uma proteção sem mediadores, utilizando-se do instituto do tombamento e de sua materialidade.

\section{A NATUREZA EXTRAORDINÁRIA DO TOMBAMENTO DOS ANTIGOS QUILOMBOS}

Ao abordar o tema da materialidade na figura do tombamento, é necessário enfatizar pontos importantes, após a promulgação da Constituição de 1988, com relação ao trato com a cultura. Nas palavras de Soares, ${ }^{45}$ "a tarefa de seleção e gestão dos bens culturais exige a construção e a fixação de parâmetros sociais, culturais, econômicos e políticos [...]. No Brasil, tais parâmetros devem seguir o que está fixado no art. 216 da Constituição". Diz o artigo:

Art. 216. Constituem patrimônio cultural brasileiro os bens de natureza material e imaterial, tomados individualmente ou em conjunto, portadores de referência à identidade, à ação, à memória dos diferentes grupos formadores da sociedade brasileira, nos quais se incluem: I - as formas de expressão; II - os modos de criar,

\footnotetext{
42 BARROSO, Luís Roberto. Fundamentos teóricos e filosóficos do novo direito constitucional brasileiro. Revista da Emerj, Rio de Janeiro, v. 15, n. 4, p. 5-37, jul. 2001. Disponível em: http://www.emerj.tjrj.jus.br/revistaemerj_online/edicoes/revista15/revista15_sumario.htm. Acesso em: 23 out. 2017. p. 33.

${ }^{43}$ CANOTILHO, José Gomes. Direito constitucional e teoria da constituição. 7. ed. Coimbra: Almedina, 1941. p. 65.

44 OLIVEIRA JÚNIOR, Vicente de Paulo Augusto de; CUNHA FILHO, Francisco Humberto. A participação da comunidade na proteção ao patrimônio cultural: uma análise do Decreto-Lei $n^{\circ}$ 25/1937 à luz da Constituição Federal de 1988. Veredas do Direito, Belo Horizonte, v. 21, n. 11, p. 215-253, jan. 2014. Disponível em: http://www.domhelder.edu.br/revista/index.php/veredas/issue/view/43/showToc. Acesso em: 19 out. 2017. p. 223-224.

45 SOARES, Inês Virginia Prado. Direito ao (do) Patrimônio Cultural Brasileiro. Belo Horizonte: Fórum, 2009. p. $40-41$.
} 
fazer e viver; III - as criações científicas, artísticas e tecnológicas; IV - as obras, objetos, documentos, edificações e demais espaços destinados às manifestações artístico-culturais; V - os conjuntos urbanos e sítios de valor histórico, paisagístico, artístico, arqueológico, paleontológico, ecológico e científico. ${ }^{46}$

Ao avalizar o dispositivo, percebe-se logo no caput do art. 216, que patrimônio cultural brasileiro ganhou uma nova conotação; passou agora a ser identificado a partir dos bens portadores de referência à identidade brasileira, seja material, seja imaterial, e ainda de diferentes grupos que compõem a sociedade nacional. Observa-se também que a proteção antes de caráter universal, no que concerne ao aspecto de uma identidade única nacional, como visto no texto do Decreto-Lei n²5/1937 ganha, segundo Cunha Filho ${ }^{47}$ uma nova nuance, "a proteção não é mais devido a um suposto interesse público universal."

Essa mudança de perspectiva traz para o instituto do tombamento uma nova visão do que poderia ser alvo do ato de tombar. Se antes o valor cultural estaria dirigido apenas a bens móveis e imóveis ligados a fatos memoráveis da história do Brasil, para a Constituição de 1988, basta apenas que sejam portadores de referência à identidade, à ação e à memória dos diferentes grupos formadores da sociedade brasileira. ${ }^{48}$

Com uma nova visão do que seria patrimônio, agora agregado ao termo cultural, faz urgir a necessidade de contextualizar a aplicabilidade do instituto de tombamento, na perspectiva constitucional e para isso "reitera-se que se deve migrar do critério da excepcionalidade para o da referencialidade", explica Cunha Filho ${ }^{49}$, ao aludir sobre a visão arraigada por longo tempo no manuseio do Decreto-Lei n 25/1937 para a visão contemporânea trazida com a Constituição de 1988.

É nessa perspectiva de excepcionalidade que reside o texto do artigo $1^{\circ}$ do Decreto-Lei $n^{\circ} 25 / 1937^{50}$, do qual se extrai que a proteção dos bens deve ser motivada, mediatamente, pelo

${ }^{46}$ MORAES, Alexandre de. Constituição da República Federativa do Brasil: de 5 de outubro de 1988. 41. ed. São Paulo: Atlas, 2015.

47 CUNHA FILHO, Francisco Humberto. A mutação do Locus Juridico do Tombamento: do direito administrativo para os direitos culturais. Publicações Escola da Agu, Brasília, v. 9, n. 3, p. 100-117, jan. 2017. Disponível em: http://seer.agu.gov.br/index.php/EAGU/issue/view/124. Acesso em: 29 nov. 2017. p. 109.

${ }^{48}$ MIRANDA, Marcos Paulo de Souza. Lei do Tombamento Comentada. Belo Horizonte: Del Rey, 2014.

49 CUNHA FILHO, Francisco Humberto. A mutação do Locus Juridico do Tombamento: do direito administrativo para os direitos culturais. Publicações Escola da Agu, Brasília, v. 9, n. 3, p. 100-117, jan. 2017. Disponível em: http://seer.agu.gov.br/index.php/EAGU/issue/view/124. Acesso em: 29 nov. 2017. p. 110.

${ }^{50}$ BRASIL. Decreto-lei $n^{\circ} 25$, de 30 de novembro de 1937. Organiza a proteção do patrimônio histórico e artístico nacional. Lex, Rio de Janeiro, DF, 1937. Disponível em: http://www6.senado.gov.br/legislacao/ListaTextolntegral.action?id=76419\&norma=10315. Acesso em: 19 out. 2017. 
interesse público, mas imediatamente "quer por sua vinculação a fatos memoráveis da história do Brasil, quer por seu excepcional valor arqueológico ou etnográfico, bibliográfico ou artístico". Em sentido complementar, o $\$ 1^{\circ}$ do mesmo artigo, determina que: “Os bens a que se refere $o$ presente artigo só serão considerados parte integrante do patrimônio histórico artístico nacional, depois de inscritos separada ou agrupadamente num dos quatro Livros do Tombo [...]". Observase que para a lei de tombamento, só seria patrimônio com valor histórico e artístico após sua inclusão nos chamados livros do tombo. Tem-se aqui uma natureza constitutiva do bem cultural.

O caput do artigo 216 da Constituição Federal mais uma vez se torna revelador quanto a essa mudança de exceção para uma diretriz de referência, pois ele afirma: “Constituem patrimônio cultural brasileiro os bens de natureza material e imaterial [...]"51, ou seja, os bens que possuírem as características exemplificadas no dispositivo, já são por natureza, patrimônio cultural. Não há a necessidade aqui de constituir por parte do Estado, através de um ato, que determinado bem seja bem cultural, cabe agora ao Estado apenas declarar o que de fato já é.

A referencialidade, como um dos pontos norteadores para o tombamento, é uma das várias características trazidas com o advento da Constituição de 1988, que deslocou tal instituto do Direito Administrativo para uma seara mais próxima dos Direitos Culturais, justamente com a finalidade de atender às mudanças de concepções implantas com a Constituição, dentre elas, a própria valorização dos Direitos Culturais.

Para Melo, ${ }^{52}$ Direito Administrativo é "o ramo do Direito Público que disciplina o exercício da função administrativa, bem como pessoas e órgãos que a desempenham”. Na outra ponta, Cunha Filho ${ }^{53}$ define os Direitos Culturais como todo direito que envolve as artes, memórias coletivas e fluxo de saberes. Especificamente sobre patrimônio cultural, argumenta: "no caso da proteção do patrimônio cultural, o foco principal é direcionado às memórias coletivas, pois a conservação de bens [...] é feita em função da lembrança do que se fez no passado que continua a existir no presente."

Ou seja, não obsta afirmar que, diante do que rege texto constitucional, os Direitos Culturais são intrínsecos à sociedade de uma forma geral, não se tratando especificamente da relação delas com o Estado ou vice-versa, como se observa no Direito Administrativo, uma vez

\footnotetext{
${ }^{51}$ MORAES, Alexandre de. Constituição da República Federativa do Brasil: de 5 de outubro de 1988. 41. ed. São Paulo: Atlas, 2015.

${ }^{52}$ MELO, Celso Antônio Bandeira de. Curso de Direito Administrativo. São Paulo: Malheiros, 2016. p. 29.

53 CUNHA FILHO, Francisco Humberto. A mutação do Locus Juridico do Tombamento: do direito administrativo para os direitos culturais. Publicações Escola da Agu, Brasília, v. 9, n. 3, p. 100-117, jan. 2017. Disponível em: http://seer.agu.gov.br/index.php/EAGU/issue/view/124. Acesso em: 29 nov. 2017. p. 106.
} 
que estes Direitos (Culturais) “possibilitam às pessoas situarem-se no tempo e no espaço, com os objetivos de incrementar o desenvolvimento e favorecer a dignidade humana."54 $\mathrm{Da}$ mesma forma, Celso Bandeira de Melo também vislumbra a possibilidade de remoção de certas áreas da alcunha do Direito Administrativo:

Isto ocorre primordialmente em razão do crescimento significativo de normas relativas a dados capítulos do Direito Administrativo e a necessidade de aprofundar-lhes o estudo ante a importância que tenham na vida social, tornando compreensível a proclamação de suas independências. ${ }^{55}$

Assim, a visão teórica de materialidade observada no corpo do Decreto-Lei $n^{\circ}$ 25/1937 merece ser questionada, sobretudo, ao tratar do tombamento de comunidades remanescentes de antigos Quilombos, haja vista, se ter uma necessidade constitucional de proteger um bem já constituído como patrimônio cultural. Com isso, o tombamento previsto no artigo 216 , § $5^{\circ}$ da Constituição adquire um contexto extraordinário, pois não há parâmetros na legislação vigente sobre como proceder tal ato administrativo, uma vez que o tombamento como encontra-se na lei gera efeitos de restrição parcial ao direito de propriedade, além destes estarem subordinados a um regime jurídico especial.

Utilizando-se do conceito observado na desapropriação extraordinária, cuja previsão constitucional encontra-se no artigo 216 , § $1^{\circ}$ como umas das formas de proteção ao patrimônio cultural e que é regulamentada pelo Decreto-Lei $n^{\circ}$ 3.365/1941 (desapropriação por utilidade pública) e Lei $n^{\circ} 4.132 / 1962$ (desapropriação por interesse social), é possível vislumbrar tal extraordinariedade no tombamento de comunidades Quilombolas, remanescentes de antigos Quilombos. Assim, é o caso de se concluir que a proteção dos antigos quilombos deve ser feita por tombamento, porque a Constituição o determina, mas nitidamente não se trata do mesmo que é disciplinado pelo Decreto-Lei $n^{\circ}$ 25/1937, que não mostra adequabilidade fáticonormativa, algo que demanda um disciplinamento específico para balizar a atuação do poder público em casos tais.

${ }^{54}$ CUNHA FILHO, Francisco Humberto. A mutação do Locus Juridico do Tombamento: do direito administrativo para os direitos culturais. Publicações Escola da Agu, Brasília, v. 9, n. 3, p. 100-117, jan. 2017. Disponível em: http://seer.agu.gov.br/index.php/EAGU/issue/view/124. Acesso em: 29 nov. 2017. p. 106

${ }^{55}$ MELO, Celso Antônio Bandeira de. Curso de Direito Administrativo. São Paulo: Malheiros, 2016. p. 38. 


\section{CONCLUSÃO}

É possível constatar, a partir da pesquisa realizada, que há um grande desafio de cunho interpretativo em se concretizar a vontade do legislador constituinte quanto à eficácia do artigo 216, § $5^{\circ}$ da Constituição Federal. No entanto, é importante sempre frisar a taxatividade contida no dispositivo, no que atine ao uso do tombamento, e quão ele é essencial para a memória do patrimônio cultural do negro no país.

A dificuldade encontrada, pelo que se conclui, recai sobre uma perspectiva de visão considerada ultrapassada no que concerne ao passado colonial brasileiro e sua formação a partir de diferentes povos. Ou seja, é necessário que o Estado atualize suas diretrizes quanto à materialidade do tombamento especificamente no caso em voga, justamente porque a própria Constituição assim exige.

O Decreto-Lei $n^{\circ}$ 25/1937, que institui as regras de tombamento, em um primeiro momento, demonstra limitações, sendo imprescindível a aplicação de uma hermenêutica ampliada e que atenda aos interesses da Constituição com referência ao artigo $216, \S 5^{\circ}$. Não obstante, cabe lembrar que a Constituição Federal se encontra no topo do ordenamento jurídico e ainda deve-se atentar que o próprio artigo traz um texto claro quanto ao mandamento constitucional ali presente.

Dessa forma, com base na Constituição, confirma-se a hipótese lançada de que as atuais ferramentas existentes para realizar o tombamento não são adequadas para levar a efeito aquele previsto no Art. 216, § $5^{\circ}$ da Constituição Federal, porque tem natureza extraordinária. Todavia, faz-se urgente a necessidade de dar cabo ao que foi determinado na Lei Maior, sob pena, inclusive, de que o decurso do tempo sem a efetivação do comando constitucional, ocasione ainda maior perda do patrimônio cultural afro-brasileiro.

É necessário estabelecer a operacionalização do preceito, se não por meio de lei ordinária específica, que se utilize a base constitucional e administrativa para essa finalidade, mas sempre com a colaboração da comunidade e, assim, garanta-se a protetiva ali exigida dentro dos mais amplos preceitos de legitimidade. 


\section{REFERÊNCIAS}

BARROSO, Luís Roberto. Fundamentos teóricos e filosóficos do novo direito constitucional brasileiro. Revista da Emerj, Rio de Janeiro, v. 15, n. 4, p. 5-37, jul. 2001. Disponível em: http://www.emerj.tjrj.jus.br/revistaemerj_online/edicoes/revista15/revista15_sumario.htm. Acesso em: 23 out. 2017.

BASTOS, Rossano Lopes. Patrimônio, Memória, Direito Cultural e Território. In: NASCIMENTO, João Carlos Nogueira et al. (Org. ). Patrimônio cultural, territórios e identidades. Florianópolis: Atilênde, 2012. p. 85-104.

BOBBIO, Norberto et al. Dicionário de Política. São Paulo: Imprensa Oficial, 2000.

BRASIL. Decreto $\mathrm{n}^{\circ} 3.551$, de 4 de agosto de 2000. Institui o Registro de Bens Culturais de Natureza Imaterial que constituem patrimônio cultural brasileiro, cria o Programa Nacional do Patrimônio Imaterial e dá outras providências. Presidência da República, Brasília, DF, 2000. Disponível em: https://www.planalto.gov.br/ccivil_03/decreto/d3551.htm. Acesso em: 28 out. 2017.

BRASIL. Decreto $n^{\circ} 4.887$, de 20 de novembro de 2003. Regulamenta o procedimento para identificação, reconhecimento, delimitação, demarcação e titulação das terras ocupadas por remanescentes das comunidades dos quilombos de que trata o art. 68 do Ato das Disposições Constitucionais Transitórias. Presidência da República, Brasília, DF, 2003. Disponível em: http://www.planalto.gov.br/ccivil_03/decreto/2003/D4887.htm. Acesso em: 28 out. 2017.

BRASIL. Decreto-lei $n^{\circ} 25$, de 30 de novembro de 1937. Organiza a proteção do patrimônio histórico e artístico nacional. Lex, Rio de Janeiro, DF, 1937. Disponível em:

http://www6.senado.gov.br/legislacao/ListaTextolntegral.action?id=76419\&norma=10315. Acesso em: 19 out. 2017

BRASIL. Instrução Normativa $n^{\circ} 56$, de 7 de outubro de 2009. Regulamenta o procedimento para identificação, reconhecimento, delimitação, demarcação, desintrusão, titulação e registro das terras ocupadas por remanescentes das comunidades dos quilombos de que tratam o Art. 68 do Ato das Disposições Constitucionais Transitórias da Constituição Federal de 1988 e o Decreto $n^{\circ}$ 4.887, de 20 de novembro de 2003. Diário Oficial da União, Brasília, DF, 9 out. 2010. Seção 1, p. 149-150.

CAMPOS, Yussef Daibert Salomão de. A dimensão política do patrimônio cultural na constituinte de 1987 - 1988. 2015. 242 f. Tese (Doutorado) - Curso de História, Instituto de Ciências Humanos, Universidade Federal de Juiz de Fora, Juiz de Fora, 2015.

CANOTILHO, José Gomes. Direito constitucional e teoria da constituição. 7. ed. Coimbra: Almedina, 1941.

CASTRO, Adler Homero Fonseca de. Quilombos: comunidades e patrimônio. 2005. Disponível em: http://www.labjor.unicamp.br/patrimonio/materia.php?id=55. Acesso em: 19 out. 2017. 
CUNHA FILHO, Francisco Humberto et al. (Org.). Proteção do patrimônio cultural brasileiro por meio de tombamento: estudo crítico e comparado das legislações estaduais organizadas por regiões. Fortaleza: UFC, 2013.

CUNHA FILHO, Francisco Humberto. A mutação do Locus Juridico do Tombamento: do direito administrativo para os direitos culturais. Publicações Escola da Agu, Brasília, v. 9, n. 3, p. 100117, jan. 2017. Disponível em: https://seer.agu.gov.br/index.php/EAGU/article/view/1977. Acesso em: 29 nov. 2017.

CUNHA FILHO, Francisco. Impacto da Constituição Federal de 1988 sobre o tombamento de bens do patrimônio cultural brasiliero. In: ENECULT - ENCONTROS DOS ESTUDOS MULTIDISCPLINARES EM CULTURA, 4., 2008, Salvador. Anais eletrônicos [...] Salvador: Ufba, 2008. p. 1-15. Disponível em: http://www.cult.ufba.br/enecult2008/14209-02.pdf. Acesso em: 20 ago. 2017.

FELIPE, Delton Aparecido. Patrimônio Cultural Negro no Paraná: A comunidade Quilombola Paiol de Telha. In: CONGRESSO INTERNACIONAL DE HISTÓRIA, 7., 2015, Maringa. Anais eletrônicos [...] Maringa: Uem, 2015. p. 3303 - 3315. Disponível em: http://www.cih.uem.br/anais/2015/trabalhos/1236.pdf. Acesso em: 19 out. 2017.

GAMA, Alcides Moreira da. 0 direito de propriedade das terras ocupadas pelas comunidades descendentes de quilombos. 2010. Disponível em: http://www.palmares.gov.br/wpcontent/uploads/2010/11/0-direito-de-propriedade-das-terras-ocupadas-pelas.pdf. Acesso em: 19 out. 2017.

GOMES, Flávio. Palmares: escravidão e liberdade no Atlântico Sul. São Paulo: Contexto, 2005.

IPHAN. Bens arqueológicos tombados. Disponível em:

http://portal.iphan.gov.br/cna/pagina/detalhes/895/. Acesso em: 28 out. 2017.

IPHAN. Conjuntos Urbanos Tombados (Cidades Históricas). Disponível em: http://portal.iphan.gov.br/pagina/detalhes/123. Acesso em: 28 out. 2017.

MELO, Celso Antônio Bandeira de. Curso de Direito Administrativo. São Paulo: Malheiros, 2016. MIRANDA, Marcos Paulo de Souza. Lei do Tombamento Comentada. Belo Horizonte: Del Rey, 2014.

MORAES, Alexandre de. Constituição da República Federativa do Brasil: de 5 de outubro de 1988. 41. ed. São Paulo: Atlas, 2015.

OLIVEIRA JÚNIOR, Vicente de Paulo Augusto de; CUNHA FILHO, Francisco Humberto. A participação da comunidade na proteção ao patrimônio cultural: uma análise do Decreto-Lei $n^{\circ}$ 25/1937 à luz da Constituição Federal de 1988. Veredas do Direito, Belo Horizonte, v. 21, n. 11, p. 215-253, jan. 2014. Disponível em:

http://www.domhelder.edu.br/revista/index.php/veredas/issue/view/43/showToc. Acesso em: 19 out. 2017. 
OLIVEIRA, Luiz Carlos Diógenes. Leis de Tombamento dos estados da região centro-oeste do Brasil perante à cidadania cultural expressa na constituição federal de 1988. In: CUNHA FILHO, Francisco Humberto et al. Proteção do patrimônio cultural brasileiro por meio de tombamento: estudo crítico e comparado das legislações estaduais organizadas por regiões. Fortaleza: UFC, 2013.

SOARES, Inês Virginia Prado. Direito ao (do) Patrimônio Cultural Brasileiro. Belo Horizonte: Fórum, 2009.

VAZ, Beatriz Accioly. Quilombos. In: GRIECO, Bettina; TEIXEIRA, Luciano; THOMPSON, Analucia (Org.). Dicionário IPHAN de Patrimônio Cultural. 2. ed. Rio de Janeiro: IPHAN, 2016. Disponível em: http://portal.iphan.gov.br/dicionarioPatrimonioCultural/detalhes/81/quilombo. Acesso em: 28 out. 2017.

Recebido em: 08.01.2018 / Revisões requeridas em: 30.08.2018 / Aprovado em: 27.09.2018 / Publicado em: 28.02.2019

\section{COMO FAZER REFERÊNCIA AO ARTIGO (ABNT):}

CUNHA FILHO, Francisco Humberto; NOGUEIRA, Paulo Sérgio Freire. A natureza jurídica extraordinária do tombamento dos antigos quilombos. Revista Eletrônica do Curso de Direito da UFSM, Santa Maria, RS, v. 14, n. 1, e30187, jan./abr. 2019. ISSN 1981-3694. Disponível em: https://periodicos.ufsm.br/revistadireito/article/view/30750 Acesso em: dia mês. ano. doi: http://dx.doi.org/10.5902/1981369430750.

Direitos autorais 2019 Revista Eletrônica do Curso de Direito da UFSM

Editores responsáveis: Rafael Santos de Oliveira e Angela Araujo da Silveira Espindola

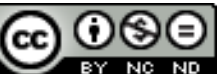

Este obra está licenciado com uma Licença Creative Commons Atribuição-NãoComercial-SemDerivações 4.0 Internacional.

\section{SOBRE OS AUTORES}

\section{FRANCISCO HUMBERTO CUNHA FILHO}

Bacharel em Direito pela Universidade de Fortaleza (1990), Mestre em Direito (Direito e Desenvolvimento) pela Universidade Federal do Ceará (1999), Doutor em Direito pela Universidade Federal de Pernambuco (2004) e Pós-Doutor pela Università degli Studi di Milano - Bicocca (2018). Atualmente é Professor Titular do Programa de Pós-Graduação em Direito Constitucional - Mestrado e Doutorado - da Universidade de Fortaleza (UNIFOR), instituição na qual lidera o Grupo de Estudos e Pesquisas em Direitos Culturais. Advogado da União - Categoria Especial. Também é acadêmico da Academia Cearense de Letras Jurídicas e Presidente de Honra do Instituto Brasileiro de Direitos Culturais - IBDCult. Tem experiência na área de Direito, com ênfase em Direitos Culturais, Direitos Humanos, Direitos Fundamentais e Direito Constitucional, atuando principalmente nos temas que Ihes são correlatos.

\section{PAULO SÉRGIO FREIRE NOGUEIRA}

Advogado com graduação em Direito pela Universidade de Fortaleza (2016) e graduação em Jornalismo pela Universidade Potiguar (2004). Atualmente é mestrando em Direito Constitucional (Conceito Capes 6) pela Universidade de Fortaleza, atuando na área de Direito Público com ênfase em Direitos Culturais, onde também é integrante do Grupo de estudos e pesquisas da referida área (GEPDC). 